\title{
Prevalence of Small Intestine Cestodes in Goat at Pegirian Slaughterhouse Surabaya \author{
Surabaya
} \\ Prevalensi Cestodes Usus Kecil pada Kambing di Rumah Potong Hewan Pegirian

\author{
${ }^{1)}$ Bryan Ahmad Affan Lubis, ${ }^{2}$ Setiawan Koesdarto, ${ }^{3)}$ Eka Pramyrtha Hestianah, ${ }^{2}$ Kusnoto, \\ ${ }^{2)}$ Lucia Tri Suwanti, ${ }^{2}$ Muhammad Yunus \\ ${ }^{1}$ Student, Faculty of Veterinary Medicine, Universitas Airlangga \\ ${ }^{2}$ Department of Veterinary Parasitology, Faculty of Veterinary Medicine, Universitas Airlangga \\ ${ }^{3)}$ Department of Veterinary Anatomy, Faculty of Veterinary Medicine, Universitas Airlangga \\ Received: 25-02-2019, Accepted: 10-03-2019, Published Online: 19-03-2019
}

\begin{abstract}
This study was conducted to determine the prevalence of small Intestine cestodes in goat at Pegirian Slaughterhouse Surabaya with gastrointestinal dissection method. Thirty-six samples of goat's small intestine, twenty-five from Kacang goats and eleven from Ettawa-cross (PE) goats, were collected from Pegirian Slaughterhouse Surabaya on May 2018. Fresh adult worms were collected with gastrointestinal dissection and microscopically identified. The result showed that cestodes infections could be identified in three (12\%) of Kacang goats and three (27.27\%) of PE goats. The cestode infections were identified five positive samples (19.23\%) in male goat and one positive sample (10\%) in female goat, while determined by the ages found three positive samples (17.64\%) in under two years old goats and three positive samples $(15.78 \%)$ in more than or equal two years old goats. The ChiSquare statistical test $(\mathrm{p}>0.05)$ showed there was no significant correlation from the race, sex, and ages of goats on the prevalence of Moniezia expansa.
\end{abstract}

Keyword prevalence, cestode, Moniezia expansa, gastrointestinal dissection

\section{Introduction}

Cestodiasis is a parasitic disease caused by tapeworm infection, one of which is gastrointestinal infection cestode. Gastrointestinal cestode infection is a tapeworm infection in the gastrointestinal tract, especially in goat. These disease cause losses, especially for goat breeders. Pegirian slaughterhouse Surabaya providing meat demand in Surabaya. The status of a goat health check at Pegirian is limited to physical health (Wirawan, 2010). The research about the prevalence of small intestine cestodes in goat at Pegirian Slaughterhouse Surabaya with gastrointestinal dissection method has never been done before. Research can expand knowledge about effect caused by the worm disease and fill in the lack of data about the prevalence of small intestine cestodiasis in goat.

Parasitic disease in livestock is the factor that can decrease livestock productivity. One of the diseases is cestodiasis or tapeworm infection because the climate which has high humidity and hot like Indonesia is ideal for worm reproduction which transmitted from soil (Beriajaya et al., 1997). The gastrointestinal parasitic worm infection is the big causes for dropping of meat production at a farm. The disadvantages which are: anorexia; dropping quality of meat, skin, and intestine; low production; and transmission to the humans or zoonosis (Gasbare et al., 2001). And according to Nofyan (2007), cestodiasis can be disadvantageous for the breeders because it can give the result in decreasing income for them. Mild until average infection not always showing the clinical sign, but chronical infection of adult tapeworm can affect gastrointestinal disorder and inhibit of young animals growing (Subekti et al., 2001).

\section{Materials and Equipments}

The experimental units that used in this research are 36 small intestine of goats from Pegirian Slaughterhouse Surabaya.

Materials that used in this research are $\mathrm{NaCl}$ 0,9\%, carmine liquid (glacial acetic acid and carmine) for Semichen-Acetic Carmin staining method, alcohol 96\%, $\mathrm{HCl}, \mathrm{NaOH}$, aquades, glycerin, Hung's I and Hung's II liquid.

The equipment that used in this research include of: rope, surgical scissors, filter, tray, 
tweezers, bowl, petri dish, and bucket. For staining method, the equipment that used are rubber string, staining jar, object glass, cover glass, and microscope.

\section{Research Plan}

This research was a survey type that has a purpose to get the prevalence of small intestine cestodes in goat at Pegirian slaughterhouse Surabaya. The positive sample counted with prevalence formula and continued with statistical calculation Chi-Square method.

\section{Sample Collection}

The substance of goat intestine used as a sample obtained by gastrointestinal dissection. That filler took by 5-7 gram and put to the plastic bag or pot filled with formalin $10 \%$ as presservative, and then labeled which contains the type and the date sample obtained.

\section{Obtaining Cestode}

Small intestine obtained from slaughterhouse tied at the two sides, after opening it pour the substance through the filter carefully and watch carefully is there any cestode or not if there is any take it and put at the petri dish that contains $\mathrm{NaCl} 0,9 \%$. The easier way of obtaining cestode, intestine substance washed carefully through the filter, and then the water goes down inside the tray to prevent the cestode washed away. This process takes over and over until the substances seen clearly, afterward the small intestine washed with little bit pressure for dropping the sticky cestode inside it.

\section{Semichen-Acetic Carmine Staining}

Coloring used as an identifying method and preserved the preparation object well for a long time. Coloring method uses Semichen-Acetic Carmine which referring to the Kuhlmann (2006). The cestode that used for preparation object can be a fresh worm or preserved worm inside the alcohol glycerin $5 \%$.

The obtained cestode then fixed between two object glass and tied with rubber string, and then put it inside staining jar filled with alcohol glycerin $5 \%$ for 24 hours. Next put at alcohol $70 \%$ for 5 minutes, continued move inside the diluted carmine liquid and wait for 8 hours depends on the thickness of the worm. After that remove the fixation and put the worm inside acid alcohol for 2 minutes continued with base alcohol for 20 minutes. Continued by doing the dehydration step with alcohol, graded start from alcohol $70 \%$ for 5 minutes, alcohol $85 \%$ for 5 minutes, alcohol $95 \%$ for 5 minutes, and then continued with mounting inside Hung's I liquid for 20 minutes, later put the worm at clean object glass and give a couple drop of Hung's II liquid on it, close it with cover glass.

\section{Data Analysis}

The obtained data analyzed with prevalences formula (Fuentes et al., 2004) for obtaining prevalence number of cestodes at small intestine slaughtered goats from Pegirian Slaughterhouse Surabaya.

To know the Correlation of prevalence of small intestine cestodes between Kacang goat and PE goat conducted statistical analysis using Statistical Product and Service Solution (SPSS) 22.0 for Windows using Chi-Square test method (Wibowo, 2002).

\section{Research Result}

Based on the result of research using 36 samples of goats small intestine at Pegirian Slaughterhouse Surabaya during May 2018, cestode obtained was Moniezia expansa, with average length $30 \mathrm{~cm}$ and $0.4 \mathrm{~cm}$ wide. One of the sample known to have a length of $60 \mathrm{~cm}$ and width $1 \mathrm{~cm}$.

The Microscopic preview of Moniezia expansa is indicated by the strobila which has hundreds and up to thousands segments. The segments are much broader than long, the proglottids has a clearly defined boundary with interproglotidal glands that spread like pearls. This is what distinguishes Moniezia expansa from Moniezia benedini which has an interproglotidal glands clustered in the middle. proglottids.

The result of laboratory examination with gastrointestinal dissection method in 36 samples divided into two races, from 25 samples of Kacang goat obtained three positive samples (12\%) infected by Moniezia expansa and 11 samples of PE goat obtained three $(27.27 \%)$ positive samples infected by Moniezia expansa, shown in Table 1.

Table 1. Prevalence of small intestine cestodes in goat determine by goat's race

\begin{tabular}{ccc}
\hline \multirow{2}{*}{ Result } & \multicolumn{2}{c}{ Race } \\
\cline { 2 - 3 } & Kacang Goat & PE Goat \\
\hline Positive & $3(12 \%)$ & $3(27.27 \%)$ \\
Negative & $22(88 \%)$ & $8(72.73 \%)$ \\
\hline Total & $25(100 \%)$ & $11(100 \%)$
\end{tabular}


Divided by their sex, from 26 samples of male goat obtained five positive samples (19.23\%) infected by Moniezia expansa and 10 samples of female goat obtained one (10\%) positive sample infected by Moniezia expansa, shown in Table 2

Table 2. Prevalence of small intestine cestodes in goat determine by goat's sex

\begin{tabular}{ccc}
\hline \multirow{2}{*}{ Result } & \multicolumn{2}{c}{ Sex } \\
\cline { 2 - 3 } & Male & Female \\
\hline Positive & $5(19.23 \%)$ & $1(10 \%)$ \\
Negative & $21(80.77 \%)$ & $9(90 \%)$ \\
\hline Total & $26(100 \%)$ & $10(100 \%)$
\end{tabular}

Divided by their ages, from 17 samples of under two years old goat obtained three positive samples $(17.64 \%)$ infected by Moniezia expansa and 19 samples of more than or equal to two years old goat obtained three $(15.78 \%)$ positive samples infected by Moniezia expansa, shown in Table 3.

Table 3. Prevalence of small intestine cestodes in goat determine by goat's age

\begin{tabular}{ccc}
\hline \multirow{2}{*}{ Result } & \multicolumn{2}{c}{ Age } \\
\cline { 2 - 3 } & $<2$ years & $\geq 2$ years \\
\hline Positive & $3(17.64 \%)$ & $3(15.78 \%)$ \\
Negative & $14(82.36 \%)$ & $16(84.22 \%)$ \\
\hline Total & $17(100 \%)$ & $19(100 \%)$
\end{tabular}

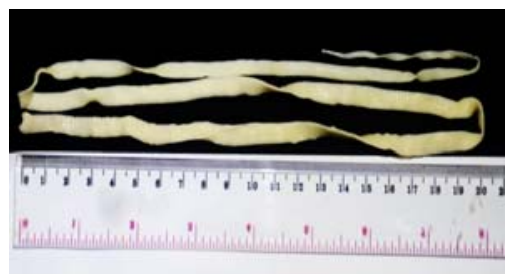

Figure 1. Macroscopic form of Moniezia expansa.

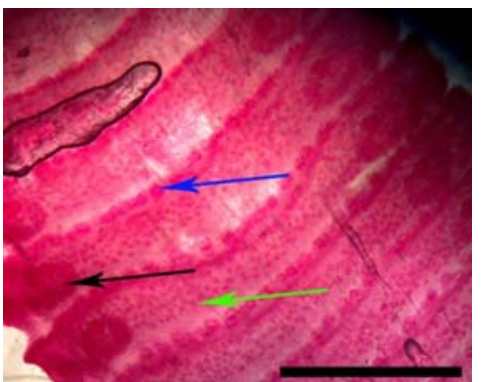

Figure 2. Proglottids part of Moniezia expansa. Genital Ovary (black arrow), testes (green arrow), and interproglottidal glands (blue arrow). (Scale bar $=3 \mathrm{~mm}$ )

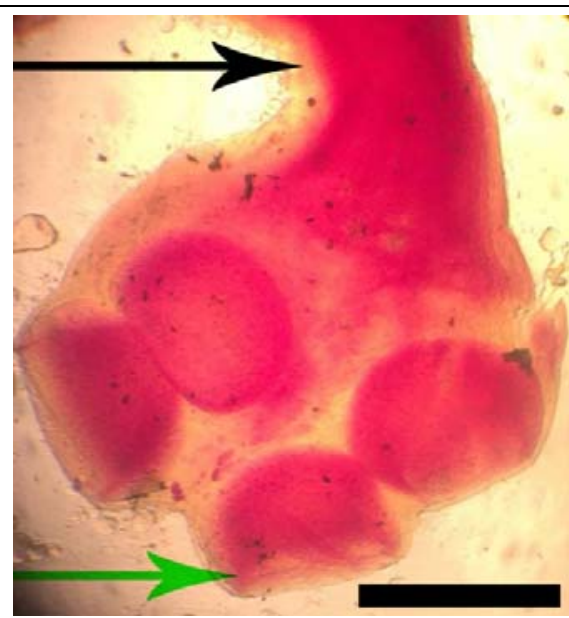

Figure 3. Scolex form of Moniezia expansa. Hookless sucker (green arrow), and neck (black arrow). (Scale bar $=0,5 \mathrm{~mm}$ )

\section{Discussion}

The result of research on 36 samples small intestine of goat slaughtered in Pegirian Slaughterhouse Surabaya was obtained Moniezia expansa tapeworm from gastrointestinal dissection method and Semichen Acetic Carmine staining method, while to identify the morphology of adult tapeworm using bare eyes and microscope.

The result of identification of adult Moniezia expansa macroscopically from six goat infected found 80 worm inside small intestine with average 13 worm per goat. They have length average on $30 \mathrm{~cm}$ and $0.4 \mathrm{~cm}$ wide with white transparent color, the strobila has hundred and up to thousands of proglottids. The segments are much broader than long. Microscopically Moniezia expansa lack digestive tracts, the head (scolex) contains four prominent suckers but no hooks. Each segment has its own reproductive organs (genital pore) of both sexes and excretory cells known as flame cells. According to Chilton et al. (2007), the size of Moniezia expansa larvae varies throughout its life cycle, containing hooks to dispel the egg.

The total of 36 samples of small intestine examined with gastrointestinal dissecting on Kacang goat obtained three (12\%) positive sample and PE goat obtained three (27.27\%) positive sample infected with Moniezia expansa. Kacang goat has the largest number of worms with average 17 worms per goat while PE goat 10 worms per goat.

Determine by the sex, Male goats of all sample obtained five (19.23\%) positive samples, whereas in female goats found one $(10 \%)$ positive sample. 
Determine by the ages three (17.64\%) positive sample in under two years old goats, and three $(15.78 \%)$ positive sample in more than or equal to two years old goats. Same as in race analysis, this is the opposite of the average number of worms found, where in under two years old goat found 10 worms per goat, whereas at more than or equal to two years old goat there are 17 worms per goat found.

Based on the three farm locations that supply livestock in Pegirian Slaughterhouse Surabaya, the Surabaya area has the highest prevalence of cestodes infection with $23.07 \%$, followed by mojokerto $15.38 \%$ and then lamongan $10 \%$.

Based on the result of statistical analysis using Chi-square test showed there was no significant correlations to the goat race between Kacang goat and PE goat and infection of Moniezia expansa in male goats and female goats in Pegirian Slaughterhouse Surabaya ( $>0.05)$.

The prevalence of cestode in the small intestine of goat is $16.6 \%$, the result is lower than research by Ananda et al. (2016) that the rate of cestode infection in goat is $29.6 \%$. The prevalence of nematodes in goats at Pegirian Slaughterhouse Surabaya reached $47.2 \%$ (Mariyam, 2017). The prevalence of trematodes in goats at Pegirian Slaughterhouse Surabaya has reached $8.33 \%$ (Kurnia, 2018). In this study did not find Avitellina centripunctata and Cysticercus tenuicollis which different from the result of research by El-Dakhly et al. (2012). This may be due to differences in species of infected goats and topographic areas of livestock.

Kacang goat is the widest meat producing goat in Pegirian Slaughterhouse Surabaya. This goat is imported from various regions, in East Java. Kacang goat known to have high adaptability to low-quality feed and extreme environmental conditions. This makes the Kacang goat easy to develop (Sarwono, 2011).

Differences of gastrointestinal cestodes most commonly found in Kacang goat and PE goat caused by the origin of goats. This is in accordance with the statement of Mukti et al. (2016) which states that the differences in prevalence and type of cestode can be caused by maintenance patterns, goat race, age, environment, geographical place, feed, sanitation, and cleanliness of the cage, and anthelmintic administration.

\section{References}

Ananda, K.J., N.K. Dhanaresh, D.S. Malatesh. 2016. Sero-Prevalence of Moneizia expansa Infection in Sheep by Indirect- ELISA Using Somatic Antigen. Veterinary Research International; 4(1): 45-49.

Beriajaya and D.B. Copeman. 1997. An Estimate of Seasonality andIntensity of Infection with Gastrointestinal Nematodes in Sheep and Goats in West Java. Jurnal Ilmu Ternak dan Veteriner; 2(4): 270-276.

Chilton, N., M. O'Callaghan, I. Beveridge, R. Andrews. 2007. Genetic Markers to Distinguish Moniezia expansa from $M$. benedeni. Parasitology Research, 100: 11871192.Devendra and Burns. 1994. Produksi Kambing di Daerah Tropis. Penerbit ITB.

El-Dakhly, Kh.M., Sh.M. Abo El-Hadid, M.A. ElAskalany, T. Yanai. 2012. An AbbatoirBased Study on Helminths of Slaughtered Sheep in Beni-Suef, Egypt. Beni-Suef University Journal of Applied Sciences; 1(1): 49-6o.

Fuentes, S.V., M. Saez, M. Trelis., C. Munosatoli, dan G.J. Esteban. 2004. The Helminth Community of Apodemus Sylvaticus (Rodentia, Muridae) in TheSierra de Gredos (Spain). Arxius de Miscel Idnia Zoologica; 2:1-6.

Kuhlmann, W.F. 2006. Preservation, Staining, and Mounting Parasite Speciment.

Mukti, F., I.B.M. Oka., and I.M. Dewinata. 2016. Prevalensi Cacing Nematoda Saluran Pencernaan pada Kambing Peranakan Ettawa di Kecamatan Siliragung, Kabupaten Banyuwangi, Jawa Timur. Indonesia Medicus Veterinus; 5(4): 330336.

Sarwono B. 2011. Beternak Kambing Unggul. Penebar Swadaya. Jakarta.

Subekti, S., S.M. Mumpuni, dan Kusnoto. 2011. Buku Ajar Ilmu Penyakit Helmint. Airlangga University Press. Surabaya.

Wibowo, E. S. 2002. Statistik Penelitian dan Aplikasinya dengan SPSS 10.o for Windows. Penerbit Alfabeta Bandung.

Wirawan, M. 2010. Survey Karkas Sapi Potong di RPH Pegirian Kota Surabaya. Sekertariat Ditjen Peternakan. 